\title{
Synthesis and Extraction Properties of $p$-tert-Butylcalix[4]arenes with Crown-5 Ether Substituents
}

\author{
Elena A. Alekseeva, ${ }^{\circledR}$ and Stepan S. Basok \\ A.V. Bogatsky Physico-Chemical Institute, National Academy of Sciences of Ukraine, 65080 Odessa, Ukraine \\ ${ }^{\circledR}$ Corresponding authorE-mail: Alyeksyeyeva@rambler.ru
}

\begin{abstract}
A series of novel lower rim calix[4]arene receptors with crown ethers moieties, i.e. 2-4, 6, 8, each of which contains 15-crown-5 ether fragment, was synthesized. The complexation properties of obtained compounds were determined through the series of alkali, alkaline earth and some transition metal picrate extraction experiments. Calixarenes with two $N$-carbonylaza(or benzoaza)crown-5 ether units $(2,3)$ are efficient extractants for alkali metal ions whereas ligands with 4-amidobenzocrown-5 ether moieties show a binding ability toward some divalent cations. The tetrasubstituted calix[4]arene 6 is an effective but non selective extractant for studied metal picrates under experimental conditions with the ligand-cation ratio 1:1.
\end{abstract}

Keywords: Calix[4]arenes, crown ether moieties, extraction, complexation.

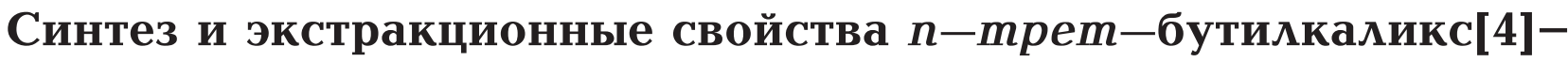 аренов с краун-5-эфирными заместителями}

\author{
Е. A. Aлексеева, ${ }^{@}$ C. С. Басок \\ Физико-химический институт имени А.В. Богатского Нацииональной академии наук Украинь,, 65080 Одесса, \\ Украина \\ @E-mail: Alyeksyeyeva@rambler.ru
}

\begin{abstract}
Представлен синтез новых рецепторов на основе каликс[4]арена, в состав заместителей которых

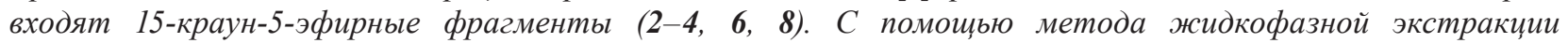
изучены комплексообразующие свойства полученных соединений относительно пикратов щелочных, щелочноземельных и некоторых переходных металлов. Показано, что каликсарень с двумя $N$-карбонилаза (или бензоаза)краун-5-эфирными заместителями $(2,3)$ являются эффективными экстрактантами шелочных металлов, в то время как лиганды с 4-амидобензокраун-5-эфирныли фрагментами демонстрируют высокое сродство по отношению к двухвалентными катионам. Тетразамещенный каликсарен 6 обладает свойствами эффективного, но не селективного экстрактанта относительно большинства изученньх пикратов металлов в условиях проведения эксперимента, предполагающих соотношение лиганд-катион - 1:1.
\end{abstract}

Ключевые слова: Каликс[4]арены, краун-эфирные фрагменты, экстракция, комплексообразование.

\section{Introduction}

Molecular recognition is one of the priorities of contemporary chemical science. ${ }^{[1-7]}$ Calixarenes substituted by molecular residues having receptor properties of "guest-host" complexation type may form an additional intramolecular cavity which can vary depending on the "guest" size and nature. Introduction of such residue as crown ether into calixarene molecule was a main task at the creation of new effective receptors based on calixarenes. Taking into account the relative rigidity of the calix[4]arene skeleton and presence of "bigger" macrocycle short linker binding to crown ether substituent one can expect a definite substituent pre-organization favouring to the metal cations 
with large ionic radius complexation of sandwich or pseudo sandwich type.

Here are just a few examples of calixarene derivatives containing at the lower rim crown ether units as a substituent. The synthesis and complexing abilities of heteroditopic calix[4]arenes containing two and four amidobenzo-15crown-5 units at the lower rim were demonstrated. ${ }^{[8]}$ It was found that calixarene with four crown ether substituents formed pentanuclear complex with sodium cations bound in crown ether moieties and tetraamide cavity. Whereas disubstituted analogue includes the cation of some s-elements in a 1:1 intramolecular sandwich stoichiometric fashion. Furthermore, these compounds demonstrated complexing ability toward the anions.

In order to obtain new receptors based on calix[4]arenes, it was decided to synthesize a series of p-tertbutylcalix[4]arene derivatives containing at the lower rim aza-, benzo- or benzoazacrown ether sites with equal size of crown ether fragment (crown-5) attached to calixarene skeleton via amide group and to compare the extraction abilities of the obtained compounds.

\section{Experimental}

Unless otherwise specified, chemicals were purchased from Across Organics (Belgium) or Merck KGaA (Germany) and used without further purification. Solvents were of HPLC grade. Reactions were carried out under argon using dry solvent, unless otherwise noted. The supporting electrolyte used in the stability constant determinations $-\mathrm{Et}_{4} \mathrm{NCl}$ (Fluka, Switzerland, $\geq 98 \%$ ) was recrystallized from methanol and dried under vacuum, for $24 \mathrm{~h}$ at ambient temperature. The preparation of the picrate salts employed in extraction experiments have already been reported. [9] The ${ }^{1} \mathrm{H}$ NMR spectra were recorded from $10 \%$ solutions in chloroform-d on a Bruker Avance DRX 500 spectrometer using tetramethylsilane as internal reference. The mass spectra were recorded on an Agilent 6530 Accurate Mass Q-TOF spectrometer with LC/MS System. The UV-Vis spectra were recorded on a UV-2401 PC spectrophotometer. Calixarenes 1, 2, 5 and 7 were synthesized according to the procedures described in. ${ }^{[10-12]}$

\section{Metal Picrate Extraction}

After mutual saturation of the solvents, equal volumes $(5 \mathrm{~mL})$ of aqueous solutions of metal picrates $\left(2.5 \cdot 10^{-4} \mathrm{M}\right)$ and solutions of the calixarenes (2-4 and 8) $\left(2.5 \cdot 10^{-4} \mathrm{M}\right)$ in $\mathrm{CH}_{2} \mathrm{Cl}_{2}$ were mechanically stirred for $1 \mathrm{~h}$ at $20^{\circ} \mathrm{C}$. After complete phase separation, the absorbance $\mathrm{A}$ of picrate ion remaining in the aqueous phase after extraction was determined spectrophotometrically at $354 \mathrm{~nm}$. For each cation-calixarene system, the absorbance measurements were repeated at least four times. Blank experiments without calixarene were run under the same conditions, yielding an absorbance $A_{0}$. The percentages of extraction of metal picrates $(\% \mathrm{E})$ were calculated as the ratio $100 \cdot\left(A_{0}-A\right) / A_{0}$ as already described in details. ${ }^{[13,14]} \mathrm{In}$ case of calixarene 6 the series of extraction experiments with concentration $1 \cdot 10^{-4} \mathrm{M}$ for the ligand and variable concentrations from $1 \cdot 10^{-5} \mathrm{M}$ to $5 \cdot 10^{-4} \mathrm{M}$ for picrate salt were performed.

\section{Stability Constant Determination}

The stability constants were determined in methanol with ligand concentration $4 \cdot 10^{-5} \mathrm{M} \cdot \mathrm{L}^{-1}$ at $25{ }^{\circ} \mathrm{C}$ and constant ionic strength $0.01 \mathrm{M}$ in $\mathrm{Et}_{4} \mathrm{NCl}$ by $\mathrm{UV}$ absorption spectrophotometry within the range $250-320 \mathrm{~nm}$ and interpreted with the program Sirko. ${ }^{[15]}$

\section{Synthesis}

General procedure for 2-4. A suspension of calixarene 1 $(0.764 \mathrm{~g}, 1 \mathrm{mM})$ and $\operatorname{HOBT}(0.3 \mathrm{~g}, 2.25 \mathrm{mM})$ in chloroform $(30 \mathrm{~mL})$ was cooled to $0{ }^{\circ} \mathrm{C}$, DCC $(0.46 \mathrm{~g}, 2.25 \mathrm{mM})$ was added, the mixture was stirred for $30 \mathrm{~min}$ at room temperature, and a suspension of $2.3 \mathrm{mM}$ of the corresponding crown ether in chloroform $(10 \mathrm{~mL})$ was added. After $12 \mathrm{~h}$, the precipitate was filtered off, solvent was evaporated in vacuo and dry residue was dissolved in chloroformbenzene $(1: 2,50 \mathrm{~mL})$, and the solution was washed in succession with water, $10 \%$ aqueous $\mathrm{HCl}$, and water again. The solvent was distilled off under reduced pressure, and the dry residue was extracted with boiling heptane $(2 \times 300 \mathrm{~mL})$. After the olvent was evaporated, recrystallisation from acetonitrile yielded a white solid.

Calixarene 6 was obtained from tetrakis(carboxymethoxy)calix[4]arene $5(0.880 \mathrm{~g}, 1 \mathrm{mM})$ in a similar manner after $25 \mathrm{~h}$ stirring.

5,11,17,23-Tetra-tert-butyl-25,27-bis [7-(2,3,6, 7,8,9,11,12octahydro-5H-1,4,10,13,7-benzotetraoxazacyclopentadecine) carbonylmethoxy]-26,28-dihydroxycalix [4] arene (cone) (3). Yield $1.13 \mathrm{~g}(90 \%)$. MS (ESI) $\mathrm{m} / z$ : $1280.9970\left[\mathrm{M}+\mathrm{H}_{2} \mathrm{O}\right]^{+}, 2515.9287$ $\left[2 \mathrm{M}+\mathrm{H}_{2} \mathrm{O}\right]^{+} .{ }^{1} \mathrm{H}$ NMR $\left(500 \mathrm{MHz}, \mathrm{CDCl}_{3}\right) \delta_{\mathrm{H}} \mathrm{ppm}: 7.50(2 \mathrm{H}$, s, OH), $6.94(4 \mathrm{H}, \mathrm{s}, \mathrm{ArH}), 6.87-6.90(8 \mathrm{H}, \mathrm{m}, \mathrm{Bzl}), 6.79(4 \mathrm{H}, \mathrm{s}$, $\mathrm{ArH}), 4.84\left(4 \mathrm{H}, \mathrm{s}, \mathrm{CH}_{2} \mathrm{CO}\right), 4.39\left(4 \mathrm{H}, \mathrm{d} J=12.96 \mathrm{~Hz}, \mathrm{ArCH}_{2} \mathrm{Ar}\right)$, $4.08\left(8 \mathrm{H}, \mathrm{m},-\mathrm{CH}_{2} \mathrm{CH}_{2}-\mathrm{O}\right), 4.00\left(4 \mathrm{H}, \mathrm{t}, \mathrm{O}_{-} \mathrm{CH}_{2} \mathrm{CH}_{2}-\mathrm{N}\right), 3.88(4 \mathrm{H}$, t, $\left.\mathrm{O}-\mathrm{CH}_{2} \mathrm{CH}_{2}-\mathrm{N}\right), 3.8\left(8 \mathrm{H}, \mathrm{m},-\mathrm{CH}_{2} \mathrm{CH}_{2}-\mathrm{O}\right), 3.67-3.73(8 \mathrm{H}, \mathrm{m}$, $\left.-\mathrm{CH}_{2} \mathrm{CH}_{2}-\mathrm{O}\right), 3.24\left(4 \mathrm{H}, \mathrm{d}, \mathrm{ArCH}_{2} \mathrm{Ar}\right), 1.21\left(18 \mathrm{H}, \mathrm{s}, \mathrm{Bu}^{\mathrm{t}}\right), 0.98(18 \mathrm{H}$, $\left.\mathrm{s}, \mathrm{Bu}^{\mathrm{t}}\right) .{ }^{13} \mathrm{C} \mathrm{NMR}\left(126 \mathrm{MHz}, \mathrm{CDCl}_{3}\right) \delta_{\mathrm{C}} \mathrm{ppm}: 30.90,31.44,31.58$, $33.54,33.70,49.39,49.55,68.39,69.05,69.38,69.51,69.58,70.77$, $73.38,113.06,113.47,120.86,121.06,124.46,125.12,127.43$, $132.44,140.65,146.23,148.24,148.44,149.76,150.98,168.41$.

5,11,17,23-Tetra-tert-butyl-25,27-bis [2-(N-2,3,5,6,8,9,11,12octahydro-1,4, 7,10,13-benzopentaoxacyclopentadecin-15-yl) carbonylmethoxy]-26,28-dihydroxycalix [4]arene (cone) (4). Yield $1.12 \mathrm{~g}(87 \%)$. MS (ESI) $\mathrm{m} / \mathrm{z}: 1312.9640\left[\mathrm{M}+\mathrm{H}_{2} \mathrm{O}\right]^{+}, 2608.8789$ $\left[2 \mathrm{M}+\mathrm{H}_{2} \mathrm{O}\right]^{+} .{ }^{1} \mathrm{H} \mathrm{NMR}\left(500 \mathrm{MHz}, \mathrm{CDCl}_{3}\right) \delta_{\mathrm{H}} \mathrm{ppm}: 10.15(2 \mathrm{H}, \mathrm{s}$, $\mathrm{NH}), 8.11(2 \mathrm{H}, \mathrm{s}, \mathrm{OH}), 7.14(4 \mathrm{H}, \mathrm{s}, \mathrm{ArH}), 7.1(2 \mathrm{H}, \mathrm{m}, \mathrm{Bzl}), 7.01$ (4H, s, ArH), 6.76, 6.85 (2H, 2H, dd, Bzl), $4.61\left(4 \mathrm{H}, \mathrm{s}, \mathrm{CH}_{2} \mathrm{CO}\right)$, $4.22\left(4 \mathrm{H}, \mathrm{d} J=13.07 \mathrm{~Hz}, \mathrm{ArCH}_{2} \mathrm{Ar}\right), 4.14\left(4 \mathrm{H}, \mathrm{t},-\mathrm{CH}_{2} \mathrm{CH}_{2}-\mathrm{O}\right)$, $4.0\left(4 \mathrm{H}, \mathrm{m},-\mathrm{CH}_{2} \mathrm{CH}_{2}-\mathrm{O}\right), 3.91\left(8 \mathrm{H}, \mathrm{t}, \mathrm{CH}_{2} \mathrm{CH}_{2}-\mathrm{O}\right), 3.78^{2}(16 \mathrm{H}, \mathrm{s}$, $\left.\mathrm{CH}_{2} \mathrm{CH}_{2}-\mathrm{O}\right), 3.53\left(4 \mathrm{H}, \mathrm{d}, \mathrm{ArCH}_{2} \mathrm{Ar}\right), 1.30\left(18 \mathrm{H}, \mathrm{s}, \mathrm{Bu}^{\mathrm{t}}\right), 1.10(18 \mathrm{H}$, $\left.\mathrm{s}, \mathrm{Bu}^{\mathrm{t}}\right) .{ }^{13} \mathrm{C} \mathrm{NMR}\left(126 \mathrm{MHz}, \mathrm{CDCl}_{3}\right) \delta_{\mathrm{C}} \mathrm{ppm}: 30.91,31.50,32.22$, $33.88,34.14,68.27,69.43,69.49,69.57,70.33,70.47,70.85,70.90$, $74.54,105.86,110.95,114.41,125.49,126.11,126.80,131.57$, 131.92, 143.23, 145.15, 148.05, 148.48, 148.74, 148.93, 164.53.

5,11,17,23-Tetra-tert-butyl-25,26,27,28-tetrakis [2-(N-2,3,5,6,8,9,11,12-octahydro-1,4,7,10,13-benzopentaoxa cyclopentadecin-15-yl)carbonylmethoxy]calix[4]arene (cone) (6). Yield $1.45 \mathrm{~g}(75 \%)$. MS (ESI) $\mathrm{m} / z$ : $1960.0637\left[\mathrm{M}+\mathrm{H}_{2} \mathrm{O}\right]^{+} .{ }^{1} \mathrm{H}$ NMR (500 MHz, $\left.\mathrm{CDCl}_{3}\right) \delta_{\mathrm{H}}$ ppm: $9.98(4 \mathrm{H}$, br.s, $\mathrm{NH}), 7.20(4 \mathrm{H}$, s, Bzl), 7.05 (4H, d, Bzl), 6.87 (8H, s, ArH), $6.69(4 \mathrm{H}, \mathrm{d}, \mathrm{Bzl})$, $4.75\left(8 \mathrm{H}, \mathrm{s}, \mathrm{CH}_{2} \mathrm{CO}\right), 3.94\left(4 \mathrm{H}, \mathrm{d} J=13.45 \mathrm{~Hz}, \mathrm{ArCH}_{2} \mathrm{Ar}\right), 3.70$ $\left(16 \mathrm{H}, \mathrm{m},-\mathrm{CH}_{2} \mathrm{CH}_{2}-\mathrm{O}\right), 3.58\left(16 \mathrm{H}, \mathrm{m},-\mathrm{CH}_{2} \mathrm{CH}_{2}-\mathrm{O}\right), 3.52$ ( $32 \mathrm{H}$, br.s, $\left.-\mathrm{CH}_{2} \mathrm{CH}_{2}-\mathrm{O}\right), 3.23$ (4H, d, ArCH $\left.4 \mathrm{Ar}\right), 1.07\left(36 \mathrm{H}, \mathrm{s}, \mathrm{Bu}^{\mathrm{t}}\right) .{ }^{13} \mathrm{C} \mathrm{NMR}$ $\left(126 \mathrm{MHz}, \mathrm{CDCl}_{3}\right) \delta_{\mathrm{C}}$ ppm: 31.15, 31.49, 33.71, 68.24, 68.27, 69.02, 69.31, 69.43, 70.03, 70.17, 70.52, 70.67, 106.91, 112.95, $113.92,125.38,131.13,132.23,145.29,145.49,148.66,152.96$, 167.78 .

5,11,17,23-Tetra-tert-butyl-25,27-bis [N-(2-ethoxy)2,3,5,6,8,9,11,12-octahydro-1,4,7,10,13-benzopentaoxacyclopentadecin-15-carbonyl]-26,28-dihydroxycalix [4]arene (cone) (8). A solution of 4-carboxybenzo-15-crown-5 $(0.32 \mathrm{~g}, 1 \mathrm{mM})$ and DCC $(0.25 \mathrm{~g}, 1.2 \mathrm{mM})$ in $\mathrm{CH}_{2} \mathrm{Cl}_{2}(10 \mathrm{~mL})$ was cooled to $-10{ }^{\circ} \mathrm{C}$ and calixarene $6(0.73 \mathrm{~g}, 1 \mathrm{mM})$ in $\mathrm{CH}_{2} \mathrm{Cl}_{2}(30 \mathrm{~mL})$ was added, after $40 \mathrm{~min}$ the temperature was raised to room. After $8 \mathrm{~h}$ stirring the precipitate was filtered off and solvent was evaporated. Recrystallisation from ethanol-water (2:1) yielded a white solid 
(1.1 g, $80 \%)$. MS (ESI) m/z: $1341.0167\left[\mathrm{M}+\mathrm{H}_{2} \mathrm{O}\right]^{+}, 2664.9755$ $\left[2 \mathrm{M}+\mathrm{H}_{2} \mathrm{O}\right]^{+} .{ }^{1} \mathrm{H}$ NMR $\left(500 \mathrm{MHz}, \mathrm{CDCl}_{3}\right) \delta_{\mathrm{H}} \mathrm{ppm}: 10.1(2 \mathrm{H}, \mathrm{s}$, $\mathrm{OH}), 7.55(2 \mathrm{H}, \mathrm{s}, \mathrm{NH}), 7.25,7.27$ (2H, dd, Bzl), 7.12 (2H, d, Bzl), 6.99-7.03 (6H, m, ArH, Bzl), $4.61\left(4 \mathrm{H}, \mathrm{s}, \mathrm{CH}_{2} \mathrm{CO}\right), 4.53(4 \mathrm{H}, \mathrm{d}$ $\left.J=13.2 \mathrm{~Hz}, \mathrm{ArCH}_{2} \mathrm{Ar}\right), 4.15-4.20\left(8 \mathrm{H}, \mathrm{m}, \mathrm{O}-\mathrm{CH}_{2} \mathrm{CH}_{2}-\mathrm{O}\right), 4.08$ (4H, t, $\left.-\mathrm{CH}_{2} \mathrm{CH}_{2}-\mathrm{N}\right), 3.88-3.92\left(8 \mathrm{H}, \mathrm{m}, \mathrm{O}-\mathrm{CH}_{2} \mathrm{CH}_{2}-\mathrm{O}\right), 3.70-3.78(16 \mathrm{H}$, m, O- $\left.\mathrm{CH}_{2} \mathrm{CH}_{2}-\mathrm{O}\right), 3.59\left(4 \mathrm{H}, \mathrm{t},-\mathrm{CH}_{2} \mathrm{CH}_{2}-\mathrm{N}\right), 3.42\left(4 \mathrm{H}, \mathrm{d}, \mathrm{ArCH}_{2} \mathrm{Ar}\right)$, $1.31\left(18 \mathrm{H}, \mathrm{s}, \mathrm{Bu}^{t}\right), 1.13\left(18 \mathrm{H}, \mathrm{s}, \mathrm{Bu}^{\mathrm{t}}\right) .{ }^{13} \mathrm{C} \mathrm{NMR}\left(126 \mathrm{MHz}, \mathrm{CDCl}_{3}\right)$ $\delta_{\mathrm{C}}$ ppm: $30.96,31.38,32.25,33.71,34.09,39.52,68.25,69.06$, $69.99,76.45,76.78,77.08,111.80,112.03,125.40,125.74,127.32$, $132.69,147.82,147.89,147.98,148.82,151.25,155.61,166.47$.

\section{Results and Discussion}

\section{Synthesis of Calixarene Containing Crown Ether Substituents}

The synthesis of di- $\mathbf{4}$ and tetrasubstituted $\mathbf{6}$ calixarenes with amido-benzo-15-crown-5 substituents from calixareneacid chlorides was described $\operatorname{in}^{[8]}$ and resulted in the
$62-65 \%$ yield target products. It was reported previously that application of a modified carbodiimide method in the presence of 1-hydroxybenzotriazole (HOBT) is rather efficient approach that allows to obtain $p$-tert-butylcalix[4]arenes (substituted in different degrees) containing the amide groups at the lower rim, with high yields..$^{[10,11]}$ This method was applied by us for calixarenes containing crown ethers units. Synthesis of calixarenes containing $N$-methoxycarbonylaza (or benzoaza)- and 4- $N$-methoxycarbonylbenzo15-crown-5 ether fragments 2-4, 6 was based on the initial 1,3-di- $\mathbf{1}$ or tetra- $\mathbf{5}$ carboxymethoxy- $p$-tert-butylcalix[4]arene derivatives in cone conformation ${ }^{[11]}$ (Scheme 1).

The way which was used for obtaining the calixarene with 4-ethoxyamidobenzocrown-5 ether $\mathbf{8}$ consists of reduction of bis(methoxycarbamoyl)-p-tert-butylcalix[4]arene 7 by the $\mathrm{B}_{2} \mathrm{H}_{6}$ in $\mathrm{THF}^{[12]}$ with following acylation of amino groups by 4-carboxybenzo-15-crown-5 ether in the presence of DCC (Scheme 2).

The ${ }^{1} \mathrm{H}$ NMR spectra of all the synthesized compounds show the typical splitting pattern for di- and tet-

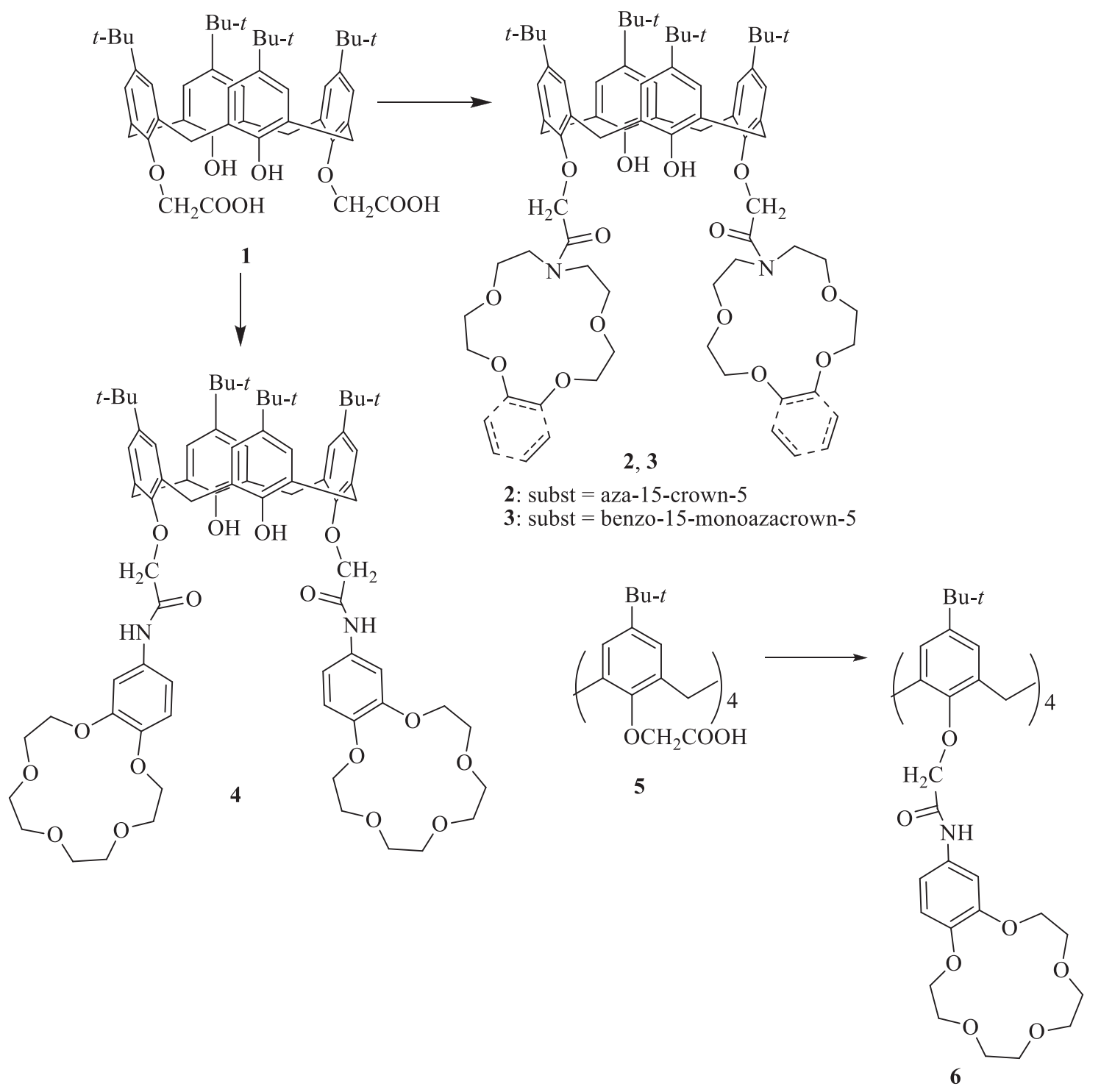

Scheme 1. Synthesis of calixarenes 2-4 and 6: DCC, HOBT, (benzo or) aza-15 crown-5 or 4-aminobenzo-15-crown-5, CHCl, $12-25$ h, $97 \%$ (2), $90 \%$ (3), $87 \%$ (4), $75 \%$ (6). 


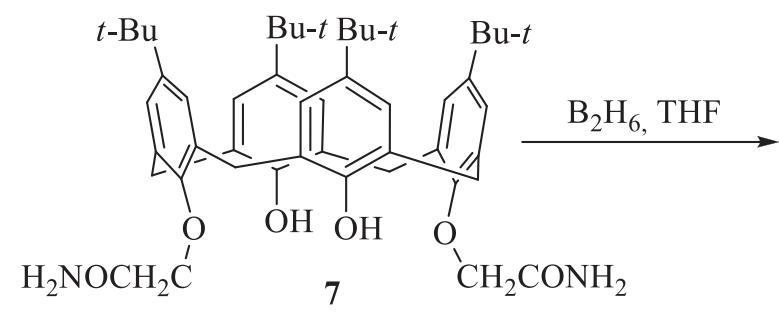

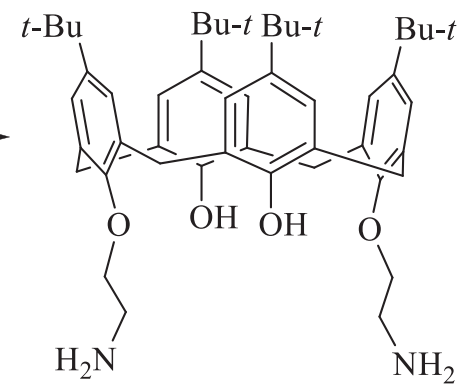

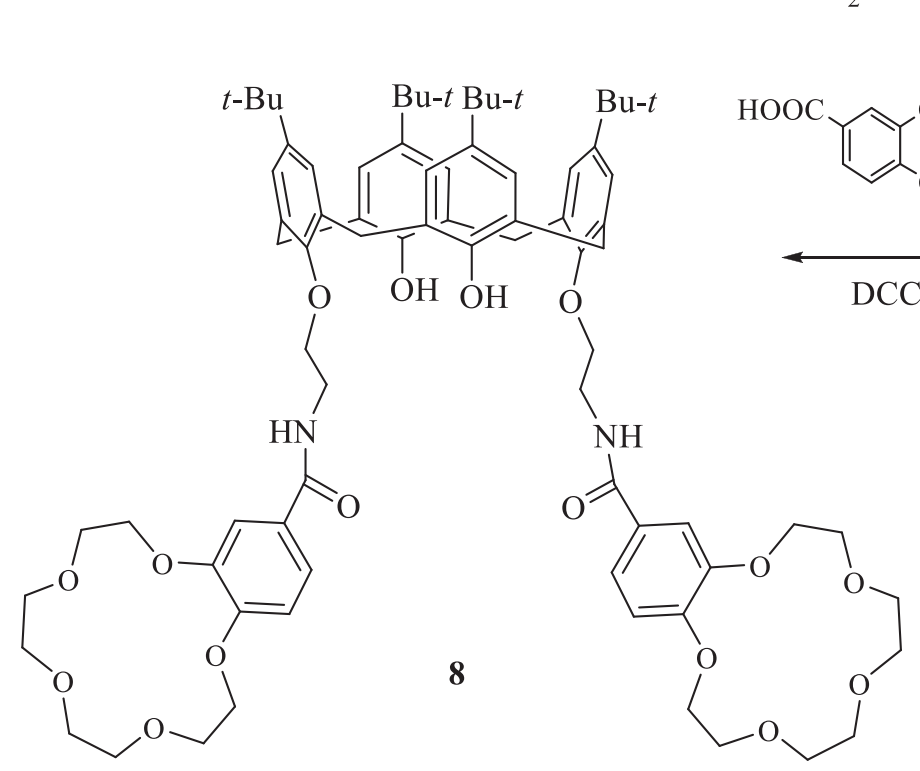

Scheme 2. Synthesis of calixarene 8 .

rasubstituted calixarenes which in solution adopt a fixed cone conformation.

\section{Extraction of Alkali, Alkaline Earth and Transition Metal Picrates}

In order to evaluate the ability of calix[4] arene with crown ether substituents to recognize metal ions, a liquidliquid extraction experiment of some alkali, alkaline earth and transition metal picrates has been carried out. The obtained results are given in Table 1 .

Study of the data in Table 1 indicates that calixarene 2 with two $N$-carbonyl-15-monoazacrown-5 ether moieties shows a remarkable preference in the extraction of sodium and potassium cations. The high affinity of $\mathbf{2}$ for the alkali cations is also reflected in complexation. As appears from our previously investigation of the complexing ability of series of calixarenes with two azacrown ether fragments this compound formed trinuclear complex with $\mathrm{Na}^{+}\left(\log \beta_{1}=5.6\right.$, $\left.\log \beta_{2}=7.8, \log \beta_{3}=7.88\right)$ and binuclear complex with $\mathrm{K}^{+}$ $\left(\log \beta_{1}=6.21, \log \beta_{2}=9.55\right){ }^{[11]}$ Calixarene 3 displays greater avidity toward $\mathrm{Na}^{+}$picrate vis-à-vis the $\mathrm{K}^{+}$picrate and $\mathrm{K}^{+}$/ $\mathrm{Na}^{+}$extraction selectivity factor $\mathrm{S}$, expressed as the ratio of the percentages extraction of potassium over sodium, is 14.16. Moreover, only this disubstituted ligand functions effectively as an $\mathrm{Rb}^{+}$extractant $\left(\% \mathrm{E}\right.$ value for $\left.\mathrm{Rb}^{+}-30 \%\right)$. However, neither $\mathbf{2}$ nor $\mathbf{3}$ demonstrated essential extraction abilities for alklaline earth metal ions and $\mathrm{Cs}^{+}$(less than $9 \%$ ).

The presence of the benzyl group near the amide fragment decreases the extraction levels for alkali metal ions in series of disubstituted calixarenes involved. Indeed, $\% \mathrm{E}$ for monovalent cations for calixarenes $\mathbf{4}$ and $\mathbf{8}$ are less than 16. Calixarene 4 with 4 -amidobenzocrown-5 ether substituents displays somewhat greater sensitivity to $\mathrm{Cs}^{+}$ picrate vis-à-vis the remaining alkali metal picrates and significantly increased extraction ability toward $\mathrm{Ba}^{2+}, \mathrm{Sr}^{2+}$

Table 1. Extraction (\%) of cations by calixarene derivatives 2-4, 6, 8 at ligand-metal ratio 1:1.

\begin{tabular}{ccccccccccccc}
\hline Compound & $\mathrm{Na}^{+}$ & $\mathrm{K}^{+}$ & $\mathrm{Rb}^{+}$ & $\mathrm{Cs}^{+}$ & $\mathrm{Ca}^{2+}$ & $\mathrm{Ba}^{2+}$ & $\mathrm{Mg}^{2+}$ & $\mathrm{Sr}^{2+}$ & $\mathrm{Cu}^{2+}$ & $\mathrm{Zn}^{2+}$ & $\mathrm{Ni}^{2+}$ & $\mathrm{Cd}^{2+}$ \\
\hline $\mathbf{2}$ & 80 & 95 & 8.5 & 9 & - & 7 & 9 & 2.3 & 4 & 2 & - \\
$\mathbf{3}$ & 6 & 85 & 30 & 9 & 2 & - & - & 7.6 & 9 & - & 1 & - \\
$\mathbf{4}$ & 5 & 10 & 6.2 & 26 & 3.8 & 21.4 & - & 18 & 18 & 5.5 & 3 & 5.6 \\
$\mathbf{8}$ & 5 & 16 & 8 & 7.4 & 10 & 36 & 18 & - & 28 & - & 1 & 50 \\
$\mathbf{6}$ & 57 & 53 & 50 & 27 & 11.4 & 8 & 13.8 & 29 & 18.7 & 4 & 18 & 16.8 \\
\hline
\end{tabular}


and $\mathrm{Cu}^{2+}$ picrates. In other hand, calixarene $\mathbf{8}$ in general shows a preference in the extraction of alkaline earth metals with the exception of $\mathrm{Sr}^{2+}$ and unusual high $\% \mathrm{E}$ values for $\mathrm{Cd}^{2+}\left(\mathrm{Cd}^{2+} / \mathrm{Na}^{+}\right.$selectivity is 10$)$. Calixarenes 3 and $\mathbf{4}$ able to form mononuclear complexes with sodium and potassium cations with $\log \beta 3.5$ and 5.5, respectively. Study on calixarenes $\mathbf{3}$ and $\mathbf{4}-\mathrm{CsCl}$ or $\mathrm{SrCl}_{2}$ interaction indicates a formation of strong 1:1 complexes of probably pseudosandwich type with $\log \beta>6$.7. On the other hand, calixarene 8 forms binuclear complex with potassium cation $\left(\log \beta_{21}\right.$ 6.4) and complexes 1:1 with calcium and barium cations with $\log \beta 3.43$ and 4.5, respectively. Analysis of results of the titration of calixarene 8 by $\mathrm{SrCl}_{2}$ in methanol demonstrates the absence of some changes in spectrum of ligand.

We were interested in abnormally low extraction percentage for $\mathrm{Ca}^{2+}$ and $\mathrm{Mg}^{2+}$ cations obtained for considered calixarenes using the standard approach for determination of picrate anion residual concentration in the aqueous phase following the experiment. Analysis of the organic and aqueous fractions attained after liquid-liquid extraction experiments indicates the re-extraction process in the case of calixarenes 2-4 and $\mathbf{6}$ containing a rigid methylene linker between amide group and calixarene oxygen atom and also demonstrates the appearance of a new absorption band at $310 \mathrm{~nm}$ that is typically for charge-transfer complexes formation. For example, distribution coefficient in waterchloroform medium for calixarene $\mathbf{6}$ is 0.06 , its magnesium and calcium complexes isolated in solid form are characterized by values of $\mathrm{D}_{\mathrm{Mg}} 1.5$ and $\mathrm{D}_{\mathrm{Ca}} 1.2$, respectively.

At the study of the calixarene $\mathbf{6}$ extraction properties relatively the alkali metals picrates the series of extraction experiments were performed at the ligandcation concentrations ratio changes. At the metals picrates concentration change from $1 \cdot 10^{-5}$ to $1 \cdot 10^{-4} \mathrm{M}$ at constant ligand concentration $\left(1 \cdot 10^{-4} \mathrm{M}\right)$ calixarene 6 demonstrates approximately the same extraction percentage for the cations of sodium, potassium and rubidium, but with the increase of the ligand-cation ratio from 1:2.5 to $1: 5$, along with a essential percentage decrease of extraction of potassium, sodium and cesium cations the selectivity increases relatively the rubidium cation, which extraction is reduced lesser than $5 \%$ (Table 2 ).

\section{Conclusion}

A new series of p-tert-butylcalix[4]arenes with $N$-carbonylmonoaza-15-, $\quad N$-carbonylbenzo-15-monoaza-, 4-amidobenzo-15-crown-5 ether moieties was synthesized. The complexation properties of new ligands were evaluated via the results of metal picrate extraction experiments. Both
Table 2. Extraction (\%) of alkali metal and strontium picrates by calixarene 6 at constant ligand concentration $\left(1 \cdot 10^{-4} \mathrm{M}\right)$.

\begin{tabular}{cccccc}
\hline $\begin{array}{c}\text { Conc. metal } \\
\text { salt (M) }\end{array}$ & $\mathrm{Na}^{+}$ & $\mathrm{K}^{+}$ & $\mathrm{Rb}^{+}$ & $\mathrm{Cs}^{+}$ & $\mathrm{Sr}^{2+}$ \\
\hline $1 \cdot 10^{-5}$ & 16.0 & 50.9 & 44.0 & 15.4 & 18.0 \\
$5 \cdot 10^{-5}$ & 18.5 & 59.2 & 52.0 & 30.1 & 23.6 \\
$1 \cdot 10^{-4}$ & 57.0 & 53.0 & 50.0 & 33.0 & 29.0 \\
$2.5 \cdot 10^{-4}$ & 20.3 & 19.3 & 47.4 & 26.8 & 14.2 \\
$5 \cdot 10^{-4}$ & 12.8 & 15.4 & 45.3 & 16.2 & 10.0 \\
\hline
\end{tabular}

of calixarenes $\mathbf{2}$ and $\mathbf{3}$ appear to function effectively as $\mathrm{K}^{+}$ extractants. Calixarene $\mathbf{8}$ displays high extraction abilities toward $\mathrm{Cd}^{2+}$ picrate and unexpected avidity toward $\mathrm{Sr}^{2+}$ ion. The tetrasubstituted calixarene with 4-amidobenzo15-crown-5 ether units displays unique selectivity as $\mathrm{Rb}^{+}$ extractant depending on the ligand-cation ratio in extraction experiments.

\section{References}

1. Molard Y., Parrot-Lopez H. Tetrahedron Lett. 2002, 43, 63556358.

2. Ali A., Salunke-Gawali S., Rao C.P., Linares J. Inorg. Chem. Commun. 2004, 7, 1298-1301.

3. Arnaud-Neu F., Collins E.M., Deasy M., Ferguson G., Harris S.J., Kaitner B., Lough A.J., McKervey M.A., Marques E., Ruhl B.L., Schwing-Weill M.J., Seward E.M. J. Am. Chem. Soc. 1989, 111, 8681-8691.

4. Bochen'ska M., Zielin'ska A., Kravtsov V.C., Gdaniec M., Luks E., Radecka-Paryzek W. Polyhedron 2002, 21, 763-768.

5. Kubo Y., Obara S., Tokita S. Supramol. Chem. 2002, 14, 461467.

6. Lee J.Y., Kim S.K., Jung J.H., Kim J.S. J. Org. Chem. 2005, 70, 1463-1466.

7. Lee S.H., Kim S.H., Kim S.K., Jung J.H., Kim J.S. J. Org. Chem. 2005, 70, 9288-9295.

8. Beer P.D., Drew M.G.B., Knubley R.J., Ogden M.I. J. Chem. Soc., Dalton Trans. 1995, 3117-3123.

9. Aggarwal R.C., Singh N.K. Defence Sci. J. 1975, 25, 153-158.

10. Alekseeva E.A., Lukyanenko A.P., Basok S.S., Mazepa A.V., Gren' A.I. Russ. J. Org. Chem. 2010, 46, 1403-1408.

11. Alekseeva E.A., Basok S.S., Mazepa A.V., Lukyanenko A.P., Snurnikova O.V., Gren' A.I. Russ. J. Gen. Chem. 2013, 83, 1738-1743.

12. Alekseeva E.A., Basok S.S., Rakipov I.M., Mazepa A.V., Gren'A.I. Russ. J. Org. Chem. 2013, 49, 1035-1041.

13. Pedersen C.J. Fed. Proc. 1968, 27, 1305-1309.

14. Bosque-Sendra J.M., Almansa-López E., García-Campaña A.M., Cuadros- Rodríguez L. Anal. Sci. 2003, 19, 1431-1440.

15. Vetrogon V.I., Lukyanenko N.G., Schwing-Weill M.-J., Arnaud-Neu F. Talanta 1994, 41, 2105-2112. 